\title{
43. Polyphenoloxidase Activation of Lentinus edodes (Berk.) Sing. Induced by Trichoderma Invasion*)
}

\author{
By Keisuke Tokimoto \\ The Tottori Mycological Institute, Tottori
}

(Communicated by Naohide Hiratsuka, M. J. A., April 12, 1980)

Species aggregates of Trichoderma, such as T. viride Pers. ex S. F. Gray, T. harzianum Rifai, T. polysporum (Link ex Pers.) Rifai, etc., are of major injurious inhabitants in cultivation of Lentinus edodes (Berk.) Sing. on bed-logs (Komatsu 1976). However, the mode of interaction between the host and the parasite varies with the nutritional milieu of media (Tokimoto and Komatsu 1977, 1979a). For example, on medium containing glucose, L. edodes develops the ability to reject Trichoderma attack, whereas on medium with xylose, the former is invaded by the latter continuously. Also, the rejecting reaction of $L$. edodes has been positively correlated with brownish pigmentation of the mycelium at the contact zone with Trichoderma. The present investigation focused on polyphenoloxidase (PPO) activity of $L$. edodes during antagonistic reaction with Trichoderma in relation to the brownish pigmentation. A part of the works has been published in the abstract (Tokimoto and Komatsu 1978).

Materials and methods. Equally to the previous paper (Tokimoto and Komatsu 1979), L. edodes, TMI-655, and three species aggregates of Trichoderma were used. Glucose medium used in this study contained (per liter of distilled water) : D-glucose $20 \mathrm{~g}$, casamino acids (vitamine free) $2.0 \mathrm{~g}, \mathrm{MgSO}_{4} \cdot 7 \mathrm{H}_{2} \mathrm{O} 0.5 \mathrm{~g}, \mathrm{KH}_{2} \mathrm{PO}_{4} 1.0 \mathrm{~g}, \mathrm{CaCl}_{2} \cdot 2 \mathrm{H}_{2} \mathrm{O}$ $0.1 \mathrm{~g}, \mathrm{FeSO}_{4} \cdot 7 \mathrm{H}_{2} \mathrm{O} 1.0 \mathrm{mg}, \mathrm{ZnSO}_{4} \cdot 7 \mathrm{H}_{2} \mathrm{O} \quad 0.9 \mathrm{mg}, \mathrm{MnSO}_{4} \cdot 4 \mathrm{H}_{2} \mathrm{O} \quad 0.8$ $\mathrm{mg}, \mathrm{H}_{3} \mathrm{BO}_{3} 1.0 \mathrm{mg}, \mathrm{CuSO}_{4} \cdot 5 \mathrm{H}_{2} \mathrm{O} 0.15 \mathrm{mg}$, Co $\left(\mathrm{NO}_{3}\right)_{2} \cdot 6 \mathrm{H}_{2} \mathrm{O} 0.1 \mathrm{mg}$, $\left(\mathrm{NH}_{4}\right)_{6} \mathrm{MO}_{7} \mathrm{O}_{24} \cdot 4 \mathrm{H}_{2} \mathrm{O} 0.2 \mathrm{mg}$, adenine- $\mathrm{HCl} 5.0 \mathrm{mg}$, and thiamine-HCl $0.1 \mathrm{mg}$. Xylose medium which contained xylose in place of glucose was also prepared. A disk of mycelium ( $5 \mathrm{~mm}$ in diameter) which was cut off from the plate culture was floated on a liquid medium $(10 \mathrm{ml}$ in 100 ml-flask), and then incubated stationarily at $25^{\circ} \mathrm{C}$ in the dark. For the study of antagonistic reaction, a disk of the plate culture of Trichoderma, $5 \mathrm{~mm}$ in diameter, was placed on a $L$. edodes mycelium colony which had been grown previously for 20 days in a liquid medium. Crude enzyme was prepared as follows: Mycelial mat and culture

*) Contribution from the Tottori Mycological Institute, no. 140. 
filtrate were separated by filtration. The mycelium was homogenized in $0.001 \mathrm{M}$ citric acid-phosphate buffer, $\mathrm{pH} 4.8$, with a Waring Blender for a total of $5 \mathrm{~min}$ ( $1 \mathrm{~min}$ of blending with $1 \mathrm{~min}$ intervals). The cell debris was centrifuged for obtaining the supernatant solution. Ammonium sulfate was added to the solution obtained or culture filtrate to bring it 0.6 saturation. After centrifugation $(15,000 \times \mathrm{g}, 20 \mathrm{~min})$, the precipitate was resuspended in $0.001 \mathrm{M}$ citric acid-phosphate buffer $(\mathrm{pH} 4.8)$ and dialyzed against the same buffer. These procedures were performed below $5^{\circ} \mathrm{C}$. PPO activity was determined using Ldihydroxyphenylalanine as a substrate, and dopachrome formation at $30^{\circ} \mathrm{C}$ was measured colorimetrically at $475 \mathrm{~nm}$. The reaction mixture contained $5 \mathrm{mM}$ of L-dihydroxyphenylalanine in $2.0 \mathrm{ml}$ of $0.03 \mathrm{M}$ citric acid-phosphate buffer, $\mathrm{pH} 4.8$, and $1.0 \mathrm{ml}$ of crude enzyme. An enzyme unit was defined as an absorbancy change of 0.001 per min. Enzyme activity was expressed in enzyme units per flask or $\mathrm{mg}$ protein. Protein concentration was determined by the method of Lowry et al. (1951) using crystallized bovine albumin as a standard. Degree of brownish pigmentation of culture medium was estimated for convenience by determining directly the optical density at $420 \mathrm{~nm}$. The zero point was adjusted with distilled water. Absorbance of 0.001 was used for a unit of pigment concentration.

Results and discussion. Similarly to the previous investigation using agar media (Tokimoto and Komatsu 1977, 1979a), rejecting reaction of $L$. edodes to Trichoderma was observed in glucose medium, but not in xylose one. In xylose medium, $L$. edodes mycelium was invaded completely by Trichoderma after ca. 5 days' incubation. However, in glucose medium, $L$. edodes rejected Trichoderma invasion at least within 8 days' interaction. The rejection of $L$. edodes coincided with brownish pigmentation of the mycelium at the contact zone with Trichoderma. Figs. 1-4 show variations of PPO activity during the antagonistic reactions. The enzyme activity of mycelium increased just after the inoculation of Trichoderma. Though the maximum points of the activity existed for periods of 1-4 days after Trichoderma inoculation, remarkable reductions occurred immediately. PPO activation in culture filtrate started 1-2 days later than that in the mycelium one. Trichoderma species produce mycolytic enzymes which lysis L. edodes mycelium, and the activity in TMI-60622 is higher than that in TMI-60147 (Tokimoto and Komatsu 1979b). It is supposed that the remarkable PPO increase in culture medium is the result of mycelium lysis of $L$. edodes by the action of Trichoderma enzymes. High PPO activities after Trichoderma inoculation are probably attributed to $L$. edodes, because no PPO activity was detected in the single cultures of Trichoderma. Without Trichoderma inoculation, PPO activity of 


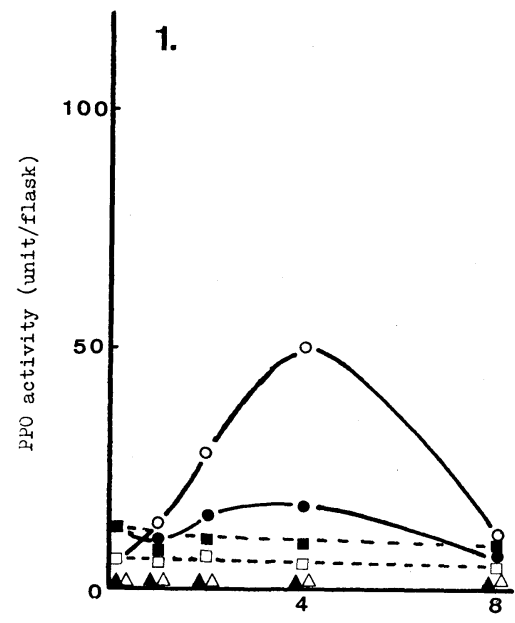

Time after inoculation (day)

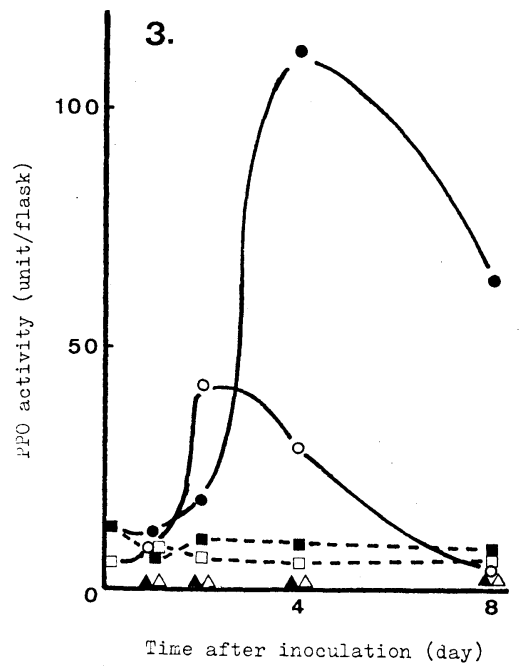

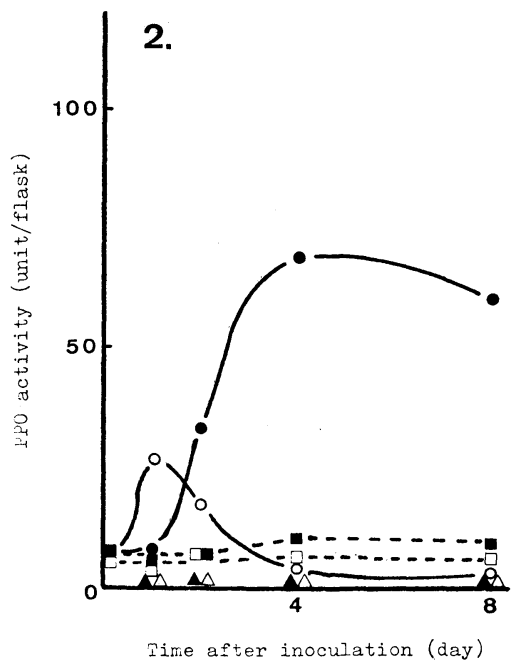

4.

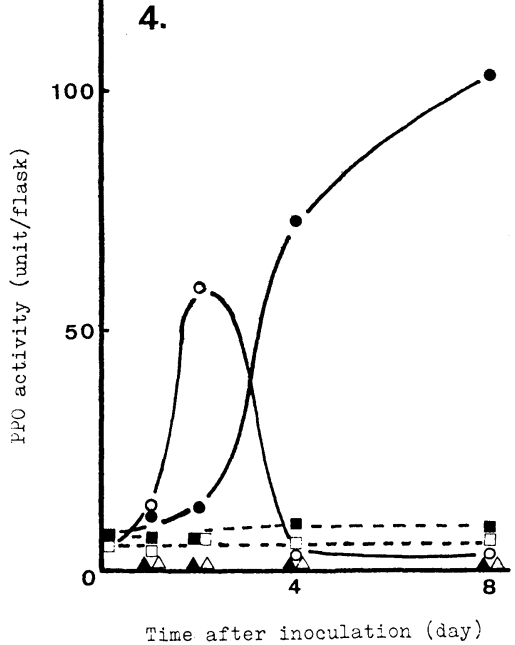

Figs. 1-4. PPO activity variations of mycelia and culture media during antagonistic reactions between Lentinus edodes (TMI-655) and Trichoderma species aggregates. Open mark, mycelium; filled mark, medium. O : Interaction between $L$. edodes and Trichoderma. $\mathbf{L}: L$. edodes single culture. $\Delta$ : Trichoderma single culture. 1, 2: T. viride, TMI-60147, was employed in glucose and xylose media, respectively. 3, 4: T. harzianum, TMI-60622, was employed in glucose and xylose media, respectively.

the mycelium and the culture filtrate of $L$. edodes maintained constant values, respectively. PPO activation of $L$. edodes was induced by the ether extracts of Trichoderma culture filtrates, though no or a little increase was observed in the case of TMI-60622 (Table I). The ether soluble fractions of Trichoderma culture filtrates inhibited mycelial 
growth of $L$. edodes, except the TMI-60622 extracts. There were negative correlations between the mycelial growth rate of $L$. edodes and PPO activity in mycelium and culture filtrate (Table I). Brownish

Table I. Effect of ether extracts of Trichoderma culture filtrates on growth and PPO activation in $L$. edodes

\begin{tabular}{|c|c|c|c|c|c|c|c|}
\hline \multirow{3}{*}{$\begin{array}{c}\text { Ether } \\
\text { extract of } \\
\text { Tricho- } \\
\text { derma* }\end{array}$} & \multirow{3}{*}{$\begin{array}{l}\text { Mycelial } \\
\text { growth } \\
\text { of } L . \\
\text { edodes** }\end{array}$} & \multicolumn{5}{|c|}{ PPO activity**** } & \multirow{3}{*}{$\begin{array}{l}\text { Brownish } \\
\text { pigment- } \\
\text { ation in } \\
\text { medium } * * *\end{array}$} \\
\hline & & \multicolumn{3}{|c|}{ per flask } & \multicolumn{2}{|c|}{ per $\mathrm{mg}$ protein } & \\
\hline & & $\begin{array}{l}\text { Myce- } \\
\text { lium }\end{array}$ & Medium & Total & $\begin{array}{l}\text { Myce- } \\
\text { lium }\end{array}$ & Medium & \\
\hline $60146 \cdot \mathrm{G}$ & 6 & 225 & 92 & 317 & 566 & 113 & 54 \\
\hline $60146 \cdot \mathrm{X}$ & 7 & 235 & 177 & 412 & 491 & 455 & 60 \\
\hline $60147 \cdot G$ & 16 & 307 & 42 & 349 & 514 & 125 & 41 \\
\hline $60147 \cdot \mathrm{X}$ & 15 & 309 & 52 & 361 & 631 & 222 & 43 \\
\hline $60622 \cdot \mathrm{G}$ & 22 & 38 & 17 & 55 & 110 & 42 & 6 \\
\hline $60622 \cdot \mathrm{X}$ & 20 & 102 & 15 & 117 & 205 & 28 & 4 \\
\hline Control & 18 & 41 & 16 & 57 & 178 & 35 & \\
\hline
\end{tabular}

* Each Trichoderma species aggregate, TMI-60146, -60147, and -60622, was grown on glucose (G) and xylose (X) media $\left(100 \mathrm{ml}\right.$ in $500 \mathrm{ml}$-flask) at $25^{\circ} \mathrm{C}$ for 10 days, respectively. The filtrates were extracted with ethyl ether after adjusting the $\mathrm{pH}$ to 3.0 , and each extract was dissolved in $5 \mathrm{ml}$ of $50 \%$ ethanol. ** To $10 \mathrm{ml}$ of glucose medium, $0.5 \mathrm{ml}$ of the extract in alcohol was added. Mycelial dry weights (mg/flask) of $L$. edodes on those media were determined after 15 days' incubation at $25^{\circ} \mathrm{C}$. *** Ether extract, $0.5 \mathrm{ml}$, was added to each $L$. edodes culture which had been grown previously for 20 days. PPO activity and brownish pigment content of medium were determined after 6 days' incubation. Each pigment content of media was expressed after deducting the one of ether extract added.

pigment of L.edodes was formed by enzymatic oxidation of polyphenols (PP), since no pigmentation occurred in the culture containing PPO inhibitor, p-aminobenzoic acid or phenylthiourea. PP content of $L$. edodes also increases after Trichoderma inoculation (Tokimoto and Komatsu 1980). PPO activation of L. edodes is induced by the mycelial damage which is caused by Trichoderma metabolites, e.g. ether soluble antifungal substances (Table I). However, breakdown of $L$. edodes mycelium results in the end of $\mathrm{PPO}$ and $\mathrm{PP}$ syntheses. In xylose medium, L. edodes seems to be damaged too severely by Trichoderma to produce the brownish pigment.

Acknowledgements. The writer wishes to express his heartiest thanks to Dr. Naohide Hiratsuka, Director of the Tottori Mycological Institute, and Dr. M. Komatsu, Chief of Breeding and Cultivation of the institute, for their cardinal help and valuable advice. He is also indebted to Prof. S. Nishimura, Tottori University, for reading the manuscript. 


\section{References}

Komatsu, M. (1976) : Rept. Tottori Mycol. Inst. (Japan), 13, 1-113.

Lowry, O. H., Rosebrough, N. J., Farr, A. L., and Randall, R. J. (1951) : J. Biol. Chem., 193, 265-275.

Tokimoto, K., and Komatsu, M. (1977) : Abstr. 2nd Intern. Mycol. Congr. (Tampa, Florida, U.S.A.), M-Z, p. 672.

- (1978): Proc. 22nd Annual Meet. of the Mycol. Soc. Japan (Tsukuba, Ibaraki), p. 83.

(1979a): Ann. Phytopath. Soc. Japan, 45, 261-264.

(1979b) : Proc. 23rd Annual Meet. of the Mycol. Soc. Japan (Otsu), p. 47.

(1980) : Proc. 1980-Annual Meet. of Phytopath. Soc. Japan (Tokyo), pp. $2-30$. 